\title{
Cynometra cebuensis, a new species of Leguminosae (Caesalpinioidae) from the Philippines
}

\section{F. Seidenschwarz ${ }^{1}$}

Key words

Caesalpinioidae

Cebu

Cynometra cebuensis

endemism

Leguminosae

Tabunan forest
Abstract A new species of Cynometra from the Tabunan forest on Cebu island in the Philippines is described.

Published on 31 May 2013

\section{INTRODUCTION}

Cebu is an island which has lost most of its forest cover early on. Rampant deforestation in the 19th century caused the Spanish authorities to act. To protect the forests of the island, all special licenses to cut trees on Cebu were cancelled in the early 1870s. In 1873, the Spanish government appointed 12 officials to prevent country-wide deforestation and to guard the remaining forests in the Philippines (Fenner 1985: 131).

However, loss of forests and biodiversity could not be stopped. Around 1950, natural forest covered only about $10 \%$ of the islands land area, and large forest areas only remained in the higher and less accessible mountains in Central and Southern Cebu (Seidenschwarz 1987: 94).

By now, the island of Cebu has only $0.2 \%$ of its natural forests left. These last remaining forest patches are unusually rich in endemic plant and animal species. The largest remnant of these original forests is the 145 ha large Tabunan forest in Central Cebu, which is renowned for its tremendous richness in rare and endangered species. The two endemic tree species so far known on the island Arthrophyllum cernabrei Merr. (Araliaceae) and Cinnamomum cebuense Kosterm. (Lauraceae) are found there. The species here described as new, stems also from the Tabunan forest, which is its only known locality.

\section{Cynometra cebuensis Seidenschwarz, sp. nov. - Fig. 1}

Cynometrae copelandii (Elmer) Elmer proxima, habitatione in sylvis siccis calcareis (versus locis planis fertilibus sylvaticis secus flumines), foliis foliolisque multo maioribus (his $4-6 \mathrm{~cm}$ versus $1.8-2 \mathrm{~cm}$ longis), inflorescentiae rhachide $14-16 \mathrm{~mm}$ longis (versus $2.5-4.5 \mathrm{~mm}$ ), antheribus basi non fissis sine stamine sterili, ovario dense strigoso (versus laxe et longe pubescenti) differt. - Typus: Seidenschwarz S.n. (holo L0820723; iso L0820722, L0820721), Tabunan forest, Cebu.

Treelet up to about $12 \mathrm{~m}$ tall; no buttresses. Leaves (3-)4-6-jugate; petioles rugose, $5-7 \mathrm{~mm}$, rachis $7.5-10 \mathrm{~cm}$, both hairy, leaflets dark green, sessile, ovate to oblong, $2-5(-6)$ by $0.8-1.5(-2.2) \mathrm{cm}$, apex deeply emarginate; base asymmetric, acroscopic side cuneate, basiscopic side rounded to auriculate;

\footnotetext{
Cebu Biodiversity Garden, Paseo Annette 1, Maria Luisa Park, Banilad, Cebu City 6000, Philippines; e-mail: cebu@hk-diplo.de.
}

midrib 5-7 mm from the acroscopic margin; nerves 7-9 pairs, margin thickened. Inflorescence rachis $14-16 \mathrm{~mm}$, laxly hairy; pedicels 8-10 mm, laxly hairy. Hypanthium $1 \mathrm{~mm}$ deep, short hairy outside. Sepals $5-7 \mathrm{~mm}$ long. Petals plain white $4-8$ by 2-4 mm. Stamens 10 sometimes 9,11 or 12 , sterile one absent, filaments $6-8 \mathrm{~mm}$ long, anthers dorsifix, not cleft at the base. Ovary $3-5$ by $1.5 \mathrm{~mm}$, densely strigose; stipe $1 \mathrm{~mm}$; style $3-5$ $\mathrm{mm}$, curved, hairy in the lower $1 / 3$, upper part glabrous, stigma $0.4 \mathrm{~mm}$. Fruit a woody pod, broadly obovoid to suborbicular, compressed, indehiscent, 4 by $2.6 \mathrm{~cm}, 2 \mathrm{~cm}$ thick, pedicel 12 $\mathrm{mm}$ long. Seed 2.2 by $1.8 \mathrm{~cm}, 1.1 \mathrm{~cm}$ thick.

Distribution - Philippines. Only known from Cebu island, (Tabunan forest in Central Cebu).

Habitat \& Ecology - In dry forests on limestone, altitude 400-600 m. Flowering occurs in March and early April, at the onset of the dry season. The flowers last only for a few days. Anthesis is three to five days. The fruits develop within 3 months and fall from the trees in July.

Notes - The species is most similar to Cynometra copelandii (Elmer) Elmer from Sibuyan island (Elmer 1910, 1915, Hou et al. 1996). Both species possess 4-6 jugate leaves and emarginate leaflets. However, the new species differs significantly in a number of characteristics. The leaves and leaflets are much larger, $4-6 \mathrm{~cm}$ vs $1.8-2 \mathrm{~cm}$ in $C$. copelandii. It also differs in several floral characteristics. The flowers are purely white, instead of creamy white. The rachis of the inflorescence is $14-16 \mathrm{~mm}$ long in the new species vs $2.5-4.5 \mathrm{~mm}$ in C. copelandii. The anthers are not cleft at the base. Elmer (1910) reports that in C. copelandii, there is one sterile stamen, which is an exception in Cynometra. The new species has no sterile stamen. The ovary is densely strigose hairy whereas it is laxly long-hairy in C. copelandii.

The habitat of the new species differs as well. It grows in dry forests on limestone without any flowing water, whereas C. copelandii is recorded as growing in "moist fertile wooded flats" along the river.

Knaap-Van Meeuwen (1970: 13) states that all Indo-Pacific species of Cynometra grow under everwet climatic conditions, but Cebu has a distinct dry season of about 3 months from the middle of March to early June. 

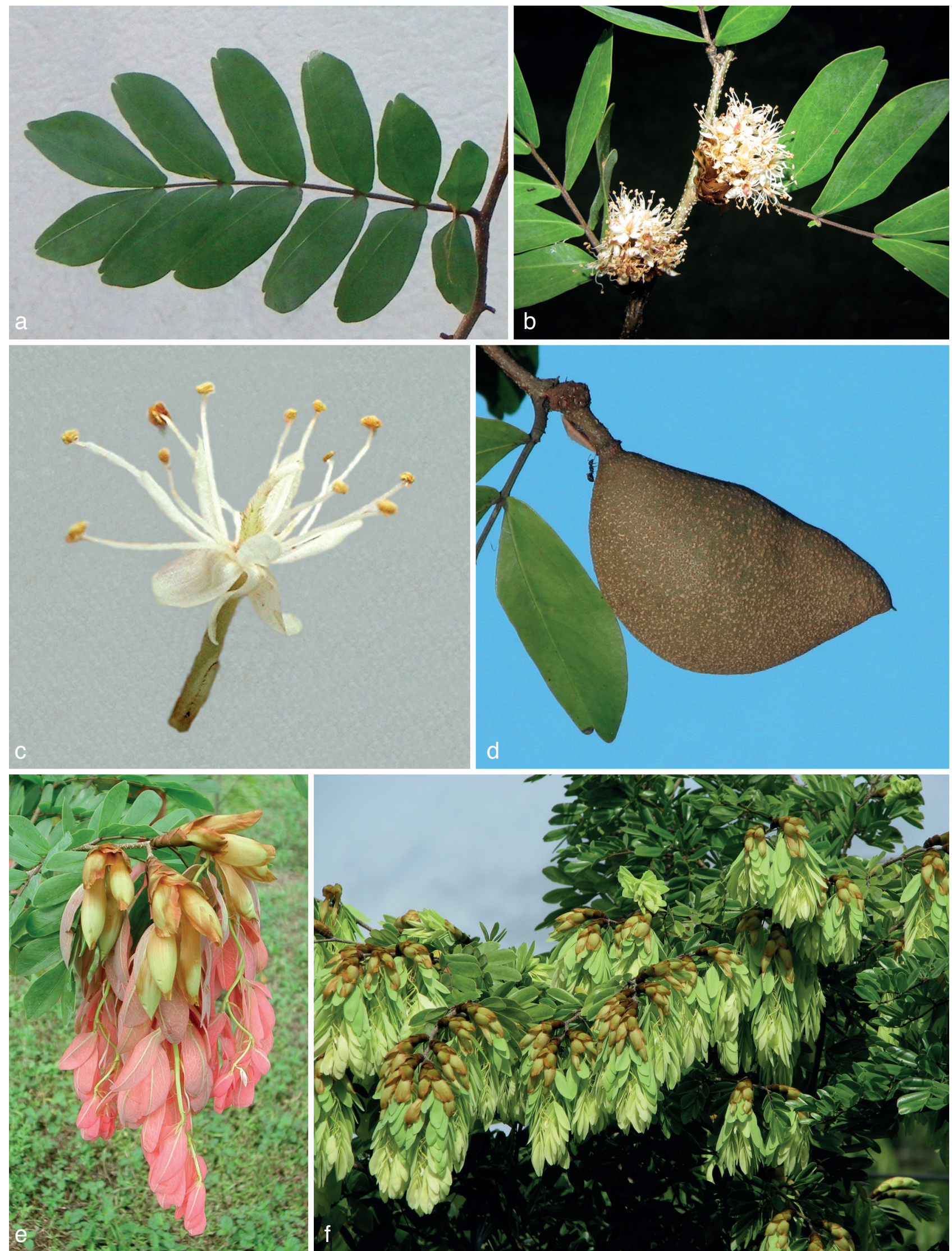

Fig. 1 Cynometra cebuensis Seidenschwarz. a. Whole leaf; b. inflorescence; c. flower; d. fruit; e. tassel in young tree; f. branch with tassels. - Photos by F. Seidenschwarz.

Growth rate \& Morphology - A study was conducted on 17 trees, raised as seedlings from the seeds of one mother tree in the Tabunan forest and planted in 1999. The first tree flowered in March 2008, i.e. nine years after planting. The new species is a slow growing tree. Average height after 10 years is only 8 meters, and the average stem diameter $8.6 \mathrm{~cm}$
New tassels are formed several times a year - mostly as single branches only. The tassels of seedlings and young trees are bright pink, in older trees, they are bright creamy greenish yellow. 
The newly opened tassels are visited by a number of insects. Observed were several species of Hymenoptera and Lepidoptera (in particular Ariadne merione luzonia).

Conservation status - Due to its restricted extent of occurrence and deteriorating habitat conditions, the new species can be classified as Critically Endangered (CR) according to the IUCN Red List Categories (IUCN 2001). The species meets the criteria B1a and B1b (as well as B2a and B2b) for Critically Endangered.

The author is monitoring the forest since 1994. The Tabunan forest covers an area of approximately $1.45 \mathrm{~km}^{2}$ and its circumference line amounts to $21 \mathrm{~km}$. The forest is surrounded by agricultural land. Habitat deterioration is caused by timber harvesting and fires during the dry season. The nearby Cantipla forest, a previous habitat of the new species, has virtually vanished. It is hoped that people will adopt the species and plant it in settlements because of its ornamental properties.
Acknowledgements I would like to thank Dr. Jan-Frits Veldkamp for his valuable suggestions and revision of the manuscript. And I wish to thank Mr. Gerhard Müller, country head of the German Development Service, for his interest and steady support in projects to propagate endangered Philippine native tree species.

\section{REFERENCES}

Elmer ADE. 1910. Gleditschia copelandii Elmer. Leaflets of Philippine Botany 2: 695

Elmer ADE. 1915. Cynometra copelandii (Elmer) Elmer. Leaflets of Philippine Botany 8: 27-34

Fenner BL. 1985. Cebu under the Spanish Flag (1521-1896). An economic and social history. San Carlos Publications, Cebu City.

Hou D, Larsen K, Larsen SS. 1996. Caesalpiniaceae. Flora Malesiana Series I, vol. 12, 2: 601

IUCN. 2001. IUCN Red List Categories and Criteria: Version 3.1. IUCN Species Survival Commission. IUCN, Gland, Switzerland and Cambridge, UK. Knaap-Van Meeuwen MS. 1970. A revision of four genera of the tribe Leguminosae-Caesalpiniaceae in Indomalesia and the Pacific. Blumea 23: 1-52. Seidenschwarz F. 1987. Forest types of Cebu Island. Philippine Quarterly of Culture \& Society 16: 93-105. 